\title{
Recovery Kawasan Bencana: Perwujudan Trauma Healing Melalui Kegiatan Psikologi dan Rohani
}

\author{
Koentjoro dan Budi Andayani
}

After Indonesia has undergone the natural disasters, it is urgent need to increase the role of psychology in coping the disaster victims. The increasing of this role is not only relating to method of help. Hence, it is needed to be stabilized a form pattern what should do to the victims. The role of psychology that focusing on the process of mental and behavior can be not centralize on the coping of stress and increasing solving behavior. Briefly, the role of psychology in this sense beside the passive coping, it needs to be an active coping.

Kata Kunci: bencana, olah rohani, trauma

$B^{2}$ arangkali ada pembaca yang ingin mengetahui mengapa psikologi banyak terlibat dalam masalah kegempaan. Psikologi adalah ilmu yang mempelajari proses mental dan perilaku, sementara itu perilaku dengan sangat jelas dirumuskan oleh Kurt Lewin sebagai fungsi dari kepribadian dan lingkungan.

Bencana Alam dapat terjadi sebagai akibat perilaku dan adanya peristiwa alam. Bencana alam sebagai akibat dari perilaku sebagai contohnya adalah fenomena banjir akibat penebangan liar atau tatakota yang tidak tertata dengan benar. Sementara itu ada juga bencana alam yang murni merupakan akibat dari peristiwa alam. Karenanya peristiwa geologi dan psikologi sangat erat kaitannya.

Indonesia adalah wilayah yang sangat rawan terjadi bencana alam. Selain wilayahnya yang dilintasi jajaran pegunungan berapi, letak di antara 2 samudera besar memberikan kemungkinan Indonesia akan terlibas bencana badai laut yang hebat. BPPT memberikan peringatan bahwa Indonesia akan menjadi sasaran Tsunami setelah Amerika Selatan dan Jepang (KR, 12-3-2003, h. 1; Jackson \& Jackson, 1996). Bencana itu selain merusak lingkungan juga menelan korban jiwa dan menyisakan stres yang berkerpanjangan pada masyarakat, karenanya tidak aneh apabila bencana alam sering disebut sebagai salah satu sumber perubahan sosial yang tidak terencana dan pembangunan disebut sebagai salah satu sumber perubahan sosial yang terencana

Perencanaan kota yang salah dan Iklim Indonesia pun menentukan terjadinya bencana. Banjir mudah terjadi ketika musim hujan dan kekeringan akan menyengsarakan pada saat kemarau. Faktor perilaku manusia memang memberi andil bagi membesarnya bencana banjir dan kekeringan.

Berbagai tempat di Indonesia pernah mengalami bencana alam yang amat dahsyat. 
Gunung Galunggung diJawa Baratpernah meletus dengan menelan korban nyawa, harta,dan benda yang tidak sedikit. Berulangkali hampir tiap tahun Gunung Merapi di Yogyakarta menyemburkan wedus gembel. Kasus lumpur panas di Sidoarjo juga bencana yang mengakibatkan korban yang lumayan besar.

Bukan hanya bencana vulkanik, tetapi bencana tektonik acapkali terjadi di Indonesia. Misalnya, pada tahun 2002 terjadi bencana tektonik yang menyebabkan Lampung porak poranda. Banyak rumah-rumah roboh, nyawa manusia melayang sia-sia.

Menurut catatan The Global Seismic Hazard Assessment Program Indonesia (periksa gambar 1) merupakan negara yang dilintasi secara sinambung jaring kerja geothermal sehingga tidak aneh jika di Indonesia rentan terjadi letusan gunung berapi, gempa bumi, retakan lapisan tanah dan semburan gas bumi. Indonesia juga termasuk kawasan kemungkinan gempa berskala tinggi.
Bencana pernah pula terjadi di Kalibayem Yogyakarta? Sebuah isu humanmade yang menyebabkan bencana sekaligus keuntungan berupa ditemukannya sumber air yang cukup besar. Kemudian bencana kebocoran depo PT KAl di Kecamatan Gedong Tengen, kesalahan teknologi ataukah keteledoran?

Bencana yang terjadi di Indonesia dapat dicermati lebih lanjut, apakah merupakan bencana alam murni ataukah akibat perilaku manusia yang salah terhadap lingkungannya.

\section{Problem Psikologis Korban Gempa}

Gempa bumi yang terjadi di Yogyakarta pada tanggal 27 Mei 2006, jam 05.55 selama 57 detik adalah murni terjadi akibat dari peristiwa alam yang kemudian memberikan pengaruh pada manusia dan menyebabkan adanya perubahan perilaku. Bencana alam itu kemudian menimbulkan

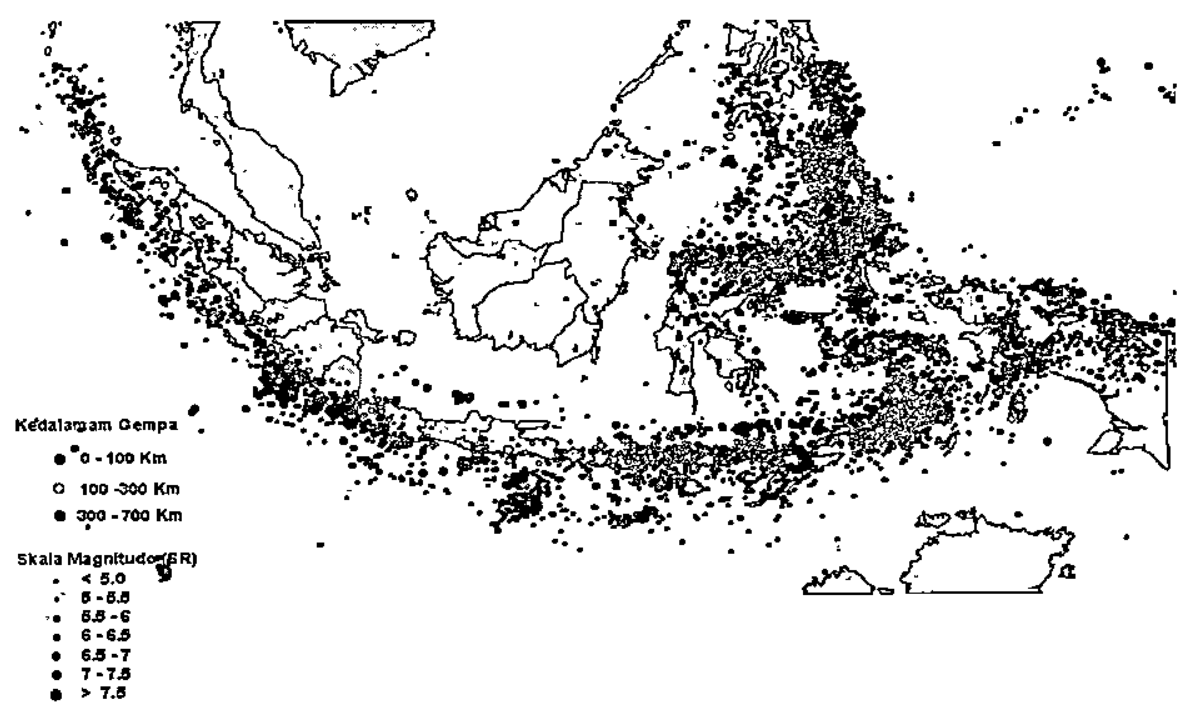

Gambar 1. Peta Seismik Menunjukkan Peristiwa Gempa di Indonesia 
problem/gangguan pada perilaku dan proses mental manusia yang menjadi korbannya. Beberapa problem psikologis yang terjadi setelah gempa itu adalah sebagai berikut.

Kecemasan. Kecemasan adalah ketakutan dengan objek, sebab dan alasan, yang tidak jelas. Kebanyakan orang amat sangat ketakutan akan adanya bahaya tsunami dan gempa-gempa susulan. Bahkan masyarakat Panggang yang berada dalam ketinggian sekitar $325 \mathrm{~m}$ di atas permukaan air lautpun amat ketakutan akan terjadi tsunami. Ketakutan atau kecemasan itu menular. Ketika ada isu tsunami terjadi ( 27 Mei 2006 jam 8 pagi, anak-anak bertanya "...ada apa to koq orang-orang pada ribut?..." "... ada tsunami..." "...Tsunami itu apa toh? Setelah dijelaskan anak baru takut. Konsep ini amat mirip dengan teori James-Lange (Huffman, dkk., 1991), bahwa emosi muncul setelah seseorang memahami bahwa suatu objek mengancam, meski respon sudah dilakukan sebelumnya.

Stres. Stres adalah kondisi yang dirasakan sangat menekan, mendorong dan menjadi beban hidup maupun psikologis yang sedemikian berat sehingga menekan fungsi keseimbangan psikologis. Problem yang muncul akibat gempa saat itu adalah rumah yang hancur, kondisi makanan yang tidak mencukupi, kehujanan, harus memikir biaya sekolah anak, banyak masalah sebelumnya yang belum terselesaikan. Pada saat yang demikian, orang menunggu janji-janji yang tidak pasti. Kesemuanya bercampur aduk menjadi satu dan menjadi beban pikiran yang berkepanjangan bagi korban.

Trauma. Trauma adalah memar secara psikologis. Sumber traumanya adalah peristiwa yang terjadi tanggal $27 \mathrm{Mei} 2006$ antara jam 05.55 hingga jam 08.00. Ketika kita masih bingung dan panik dengan kejadian gempa yang memakan korban tanggal 27 Mei 2006 antara jam 05.55; tibatiba terjadi gempa susulan pada jam 08.00; banyak orang pada ribut berlarian sambil berteriak: “... tsunami ... tsunami ..." Memar psikologis itu sebenarnya dapat sembuh dengan sendirinya. Hanya saja kesembuhan itu sulit dicapai sebab hingga berbulan-bulan kemudian gempa-gempa susulan masih saja terjadi, dan korban tidak tahu kapan gempa susulan itu akan berhenti.

\section{Dampak cemas, stres dan trauma}

Masyarakat menjadi amat mudah digoncang oleh adanya rumor. Ada beberapa rumor yang tercatat yaitu (1) menurut NHK pada jam sekian akan terjadi gempa susulan yang lebih hebat dibanding gempa utama; (2) Menurut radio Australia pada jam 23.00 akan diguncang gempa susulan yang lebih hebat; (3) Menurut ramalan Jayabaya, Jawa akan terpecah menjadi 2; (4) menurut berita pada jam 06.00, tanggal 06 Juni tahun 2006 akan ada gempa hebat; (5) pada tanggal 27 Juni akan ada gempa; (6) gempa akan terjadi lagi pada tanggal 13 Juli; (7) gempa bakal terjadi lagi antara tanggal tanggal 13-16 Juli. Gempa susulan memang masih saja terjadi, meski dengan skala lebih kecil dan durasi yang lebih singkat. BMG sebagai badan yang mempunyai kewenangan memberikan informasi tentang kegempaan seharusnya lebih aktif mewartakan kondisi dan situasi kegempaan kepada masyarakat,karena intensifnya kecemasan dan banyak isu yang muncul, keaktifan BMG akan sangat membantu apabila pewartaan ditingkatkan frekuensinya, misainya setiap 4 jam sekali BMG menggunakan media radio/TV untuk mewartakan kondisi gempa dan situasi kegempaannya.

Di Sanden dan Sumber Agung, Jetis; Sriharjo, Imogiri; dan Nambangan, Seloharjo, 
Pundong; setiap kali ada gempa susulan, kenthongan dipukul bertalu-talu. Tidak lama setelah kenthongan dipukul anak-anak balita khususnya kemudian menangis. Kenthongan dipukul mempunyai asosiasi dengan ketakutan. Hal ini kemudian mengkondisikan anak-anak menjadi ikut ketakutan tanpa tahu apa yang harus ditakutkan. Hal ini menunjukkan bahwa ketakutan bersifat menular, sehingga perlu diusahakan agar respon ketakutan tidak muncul secara impulsif, dan hal ini termasuk pula memukul kenthongan. "Bahwa ketakutan itu mudah menular" setiap relawan hendaknya memahami kalimat tersebut,kenapa? Tujuan relawan menolong adalah untuk mengurangi beban penderitaan baik fisik maupun psikologis korban bencana,sehingga aneh apabila yang terjadi relawannya setiap kali ada gempa susulan masih stres dan cemas. Kondisi ini jelas akan sangat berpengaruh memperburuk kondisi mental psikologis korban yang sudah mulai pulih.

Dampak lain adalah problematika suami-isteri untuk melaksanakan hajat pemenuhan kebutuhan seksualnya. Suami dan istri dalam suasana stres dan tegang namun juga dihadapkan pada tuntutan seks yang adiksi, dengan tidak didukung tempat yang aman dan nyaman akibatnya hubungan seks-suami istri menjadi terganggu.Padahal bagaimanapun hubungan seks suami-isteri ini apabila berjalan normal maka akan dapat menjadi bagian terapi rekreasional di tengah penderitaannya.

Beban berat dan kecemasan yang tinggi juga dirasakan oleh petugas asesor kerusakan rumah. la dihadapkan pada konflik antara tugas negara, kemanusiaan, dan relasi pertetanggaan yang tidak didukung skill untuk melakukan assessment. Keluhan mereka sebagai berikut: "... wah berat pak orang seperti saya.... bukan orang STM disuruh memeriksa kerusakan rumah korban gempa... Dari pemerintah begini...dari warga begini..." Bahkan di suatu tempat: “... Pak RT kemarin diajak berkelahioleh warganya gara-gara numahnya yang rusak cukup berat dikatakan ringan..."

\section{Kecacatan dan Disfungsi Organ}

Hal yang membedakan dari akibat gempa di Yogyakarta dan dan gempa-tsunami di Aceh adalah bahwa penderita cacat dan disfungsi organ sebagai akibat bencana diAceh lebih sedikit dibanding di Yogyakarta dan Klaten. Di Yogyakarta dan Klaten akan banyak dijumpai penderita cacat yang akan menjalani kecacadannya sepanjang hidupnya. Kita dapat menduga bahwa kecacadan itu banyak disebabkan karena remuknya tulang belakang akibat kejatuhan tembok kala gempa terjadi. Apabila ini benar maka banyak orang akan mengalami kelumpuhan, akibatnya akan banyak yang kehilangan lapangan pekerjaan dan terjadi disfungsi seksual. Adanya kecacatan ini merubah kepercayaan diri, pola kehidupan dan penyesuaian dirinya. Banyaknya orang yang mengalami kecacatan diperlukan penanganan psikologis jangka panjang bagi korban sangat diperlukan.

Dari uraian di atas tampak bahwa pada dasarnya bencana selain menimbulkan kerusakan fisik juga mempunyai dampak psikologis yang tidak dapat diabaikan. Dampak psikologis ini tidak terbatas pada sisi individu saja, melainkan juga dampakdampak psikososial. Hal ini memperkuat pentingnya psikologi berperan dalam penanganan korban bencana.

\section{Penanganan Psikologis Korban Gempa}

Indonesia terletak di wilayah gempa dan pada kenyataannya gempa bumi terjadi dimana-mana, oleh karena itu penduduk In 
donesia perlu mengubah set mental terhadap gempa dengan menjadikan gempa bumi sebagai bagian dari kehidupan. Dengan menjadikan gempa sebagai bagian kehidupan berarti setiap orang telah siap jika terjadi bencana gempa bumi. Hal ini dimulai kebijakan-kebijakan tentang pembangunan fisik, mulai dari segi konstruksi dan pemilihan lahan, hingga manajemen lingkungan baik dalam skala masyarakat yang lebih luas mau pun pribadi. Selain itu, secara psikologis setiap orang perlu dipersiapkan menghadapi bencana, antara lain (1) Meningkatkan daya kritis dan rasionalitas warga dengan cara meningkatkan kemampuan warga untuk mampu membedakan fakta dan analisis. Hal ini diperlukan agar warga tidak mudah dipengaruhi oleh rumor sehingga tidak pula mudah mengalami ketakutan dan stres karena seolah masalah datang bertubi-tubi. (2) Mengerti dan mampu melakukan langkahlangkah yang harus dilakukan ketika menghadapi bencana, khususnya dengan penyelamatan diri, aset dan dokumen. Kesiapan seperti ini akan memudahkan orang ketika bencana datang. Pada umumnya, orang akan secara spontan melarikan diri dari bahaya, dan tidak akan teringat akan penyelamatan aset dan dokumen yang berharga dalam kehidupan selanjutnya. Apabila hal ini sudah disiapkan maka ketika ada bencana segala sesuatunya lebih mudah dilakukan. (3) Mampu berserah diri secara total kepada Sang Pencipta. Tidak ada manusia yang dapat mengatasi sendiri segala persoalannya. Keberagamaan akan sangat membantu manusia dalam menghadapi persoalan-persoalan hidup karena keyakinan kepada Sang Pencipta akan mampu memotivasi manusia untuk tetap bertahan dan berusaha mengatasi persoalannya.

Kesiapan menghadapi bencana merupakan satu modal bagi setiap orang untuk mengatasi permasalahannya. Namun demikian, setiap orang tidaklah sendiri. Ketika terjadi bencana pertolongan akan datang pula dari berbagai pihak. Setiap kali terjadi bencana di suatu tempat simpati akan datang dari mana-mana, dan relawan pun datang untuk memberikan pertolongan.

Satu hal yang perlu dimengerti adalah bahwa pada dasarnya menolong berarti memberi, dan memberi bukanlah suatu pekerjaan yang mudah. Apalagi memberi pertolongan. Seseorang kasihan melihat penderitaan anak jalanan, dan setiap ada anak jalanan ia memberi uang, meski hanya Rp. 100,-. Namun ternyata semua orang berpikiran sama akibatnya anak jalanan ini dengan mudah mendapatkan uang, dan hal ini membuatnya malas berbuat lain yang lebih human. Mengingat alasan tersebut maka diusulkan agar pemberian pertolongan korban gempa penanganannya berbasis pada pendekatan Community Development, dengan menekankan pada pentingnya optimalisasi partisipasi sosial masyarakat, kemandirian masyarakat, dan kesejahteraan sosial masyarakat. Dengan mendasarkan pada ketiga hal tersebut, segala langkah penanganan masyarakat sebagai tujuannya diarahkan kepada self-help group yang di antaranya adalah terbentuknya peer counselor.

Terbentuknya self-help group akan lebih efektif dalam menangani korban, sehingga orang dewasa pada umumnya yang terdiri dari para orangtua, guru, dan tokoh masyarakatlah yang perlu menjadi sasaran utama dalam suatu intervensi. Ketika orang dewasa sudah mampu mengatasi persoalannya, barulah perhatian ditujukan kepada anak-anak. Selama ini penanganan korban gempa banyak terfokus pada anak-anak, entah dengan tujuan mengalihkan perhatian dari kesusahan akibat bencana, misalkan dengan kegiatan nyanyi, atau menggambar, 
atau pun agar kehidupan sehari-hari anak tetap berlangsung dengan cara mendirjkan sekolah darurat dan relawan datang dan melakukan kontak dengan anak-anak, hal ini akan membangun kedekatan baru pada anak-anak dengan orang-orang baru. Hanya saja, relawan tidak dapat selamanya melakukan kontak dengan anak-anak, mereka harus pergi karena program dan dana yang terbatas. Akibatnya, anak-anak pun akan merasakan kehilangan, dan seolah terjadi bencana psikologis yang kedua.

Penanganan gempa pada anak pada dasarnya perlu terencana dan terprogram, serta dilakukan oleh mereka yang memahami dunia psikologi anak. Penanganan korban anak secara salah dapat menyebabkan trauma pada anak makin dalam, dan makin sulit disembuhkan.

Penanganan psikologis untuk korban gempa, dengan dasar terbentuknya self-help group membutuhkan pemahaman konsep dan cara pendekatan. Pemahaman yang pertama adalah pemahaman akan dukungan sosial. Dukungan sosial adalah suatu usaha yang mengarah pada peningkatan kesejahteraan individu yang menerima dukungan (Sarafino, 1990). Hal ini dapat dilakukan dengan berbagai cara, sehingga dukungan sosial dapat dibedakan atas berbagai jenis dukungan sosial. Dukungan sosial dapat berupa pemberian informasi baik secara verbal maupun non verbal, pemberian bantuan tingkah laku atau materi. Oford (1992) mengemukakan bahwa ada lima dimensi fungsi dasar dukungan sosial, yaitu: (a) dukungan materi, yaitu dukungan yang berupa bantuan nyata (tangible aid) atau dukungan alat (instrumental aid); (b) dukungan emosi, yaitu dukungan yang berhubungan dengan hal yang bersifat emosional atau menjaga keadaan emosi, afeksi atau ekspresi; (c) dukungan penghargaan, yaitu dukungan yang terjadi bila ada ekspresi penilaian yang positif terhadap individu; (d) dukungan informasi, yaitu pemberian informasi yang diperlukan oleh individu; dan (e) dukungan integritas sosial, yaitu perasaan individu sebagai bagian dari suatu kelompok. Dengan demikian secara psikologis, dukungan sosial, apa pun bentuknya, akan memberikan pemahaman dan perasaan bahwa seseorang diperhatikan, bernilai dan berharga bagi orang lain, dan perasaan dicintai. Hal ini akan menjadikan individu yang, mendapat dukungan sosial menjadi lebih bersemangat dalam menjalani kehidupannya. Mallinchrodt dan Fretz (1988) menunjukkan bahwa sejumlah penelitian menemukan hubungan yang erat antara dukungan sosial dan kemudahan dalam penyesuaian individu dalam menghadapi kesulitan hidup. Dengan demikian, dukungan sosial menjadi suatu hal yang penting dalam usaha memberikan pertolongan.

Dukungan sosial itu sendiri, ada atau tidaknya, merupakan suatu kondisi yang dipersepsi oleh penerima (Afiatin \& Andayani, 1998). Hal ini berarti apakah dukungan itu ada dan dirasakan tergantung pada persepsi seseorang. Dengan demikian, konsep operasional dari dukungan sosial yang dipakai adalah perceived support (dukungan yang dirasakan) yang memiliki dua elemen dasar, yaitu (a) persepsi bahwa ada sejumlah orang lain yang dapat diandalkan individu ketika ia membutuhkan, dan (b) derajat kepuasan terhadap dukungan yang ada.

Relawan, dalam kegiatannya memberikan bantuan kepada korban gempa, selain jtu juga penting memberikan keyakinan kepada para korban bahwa mereka tidak sendiri. Selain ada sanak-saudara atau pun tetangga yang juga menjadi korban mereka perlu pula diyakinkan bahwa banyak orang lain yang peduli terhadap mereka. Tentu 
saja, hal ini bukan merupakan usaha meyakinkan yang hanya kosong belaka. Keberadaan relawan sendiri perlu memberikan perasaan aman dan terlindungi bagi para korban tanpa harus kemudian mereka dikecewakan oleh janji-janji kosong belaka.

Memberikan dukungan sosial tidak dapat dikatakan sebagai suatu pekerjaan yang mudah. Secara umum seorang relawan diharapkan ada dalam kondisi mental psikologis yang seimbang. Jika seorang relawan sendiri sedang mengalami masalah dan kesulitan mengatasinya, ada kemungkinan tantangan dan tekanan saat berada di antara korban gempa akan justru menambah beban psikologis bagi relawan tersebut. Akibatnya, bukannya relawan dapat memberikan dukungan sosial, ia justru menjadi beban bagi sesama relawan dan tidak mampu menjalankan perannya sebagai relawan.

Satu faktor psikologis yang perlu diperhatikan dalam penanganan korban gempa adalah pemahaman korban menurut budaya lokalnya. Ada fenomena yang amat menarik yang terkait dengan korban gempa. Tidak jarang penulis menanyakan kepada korban tentang kondisi rumah dan keluarga. Penuljs mendapatkan jawaban amat mengejutkan: "...Kathah rencange..." (banyak temannya), atau "...mboten miyambaki (tidak sendirian)..." Penulis sangat jarang mendengar orang mengeluh karena gempa.Ditinjau dari perspektif psikologi sosial, respon-respon seperti itu mengandung konsep social loafing dan perilaku collective, yaitu adanya perasaan senasib sepenanggungan. Meski responrespon seperti ini merupakan suatu respon positif, perlu pula diwaspadai dan kehatihatian dalam penanganan korban gempa. Social loafing dan kolektivisme dalam hal berpikir positif pun dapat berubah menjadi perasaan negatif dan menimbulkan riot ketika orang merasa diperlakukan tidak adil.

Pemahaman yang berikutnya terkait dengan kemampuan membedakan fakta dan hasil analisis. Kemampuan ini akan mengarahkan kepada kepekaan dan tidak mudah diombang-ambingkan oleh rumor yang muncul. Kemampuan semacam ini dalam pengalaman penulis sangat mempengaruhi persepsi seseorang tentang suatu fenomena dan selanjutnya pada pengambilan sikap dan keputusan. Satu contoh yang dapat diajukan di sini adalah kecenderungan orang untuk mengembangkan satu informasi menjadi besar sehingga menjadi gosip atau rumor.

Sebagai contoh tentang isu tsunami setelah gempa 27 Mei 2006 lewat. Konon, faktanya adalah ada air menggenang di suatu daerah di bagian selatan Yogyakarta. Air yang menggenang segera dianalisis dan diasumsikan sebagai lidah air dari laut selatan yang naik karena tsunami. Warga yang panik segera melarikan diri dan mengungsi, ke arah utara. Faktanya, di jalan banyak kendaraan baik sepeda motor máupun mobil dan truk berbondong-bondong dari arah selatan menuju utara, dan teriakan peringatan akan tsunami terdengar di manamana. Situasi ini dianalisis sebagai suatu kebenaran akan adanya tsunami dan membuat orang yang tinggal di daerah utara pun panik dan berusaha menyelamatkan diri (seorang tetangga penulis bahkan naik ke atas atap karena tidak tahu lagi harus lari ke mana). Pada saat seperti ini, sepotong fakta menjadi lebih penting daripada faktafakta lain yang dapat mematahkan asumsi. Kota Yogyakarta sendiri yang letaknya kurang lebih $27 \mathrm{~km}$ dari laut selatan, yang dibentengi pertama oleh bukit-bukit pasir di tepi pantai, dan selanjutnya oleh bukit-bukit kapur di wilayah Gunung Kidul, serta tinggi kota Yogyakarta adalah $112 \mathrm{~m}$ di atas 
permukaan laut, menjadi fakta yang tidak dianalisis pada saat itu.

Fenomena tersebut di atas menunjukkan bahwa daya kritisi masyarakat masih sangat rendah sehingga mudah terpengaruh oleh isu dan rumor. Mengingat kecenderungan masyarakat masih sulit membedakan fakta dari analisis atau interpretasi, masih ada kemungkinan pula para relawan yang belum mampu melakukannya pula. Hal ini dapat membahayakan stabilitas situasi, karena tidak jarang relawan terkena rumor dan justru memicu rumor baru pada korban gempa.

Perlu pula dipahami bahwa setiap orang yang mengalami masalah atau tekanan psikologis membutuhkan tempat untuk meringankan tekanan atau stres tersebut. Tempat curhat, atau dalam bahasa psikologi disebut media katarsis, menjadi sangat penting dalam pemberian bantuan kepada korban gempa. Media katarsis dapat pula ada dalam berbagai bentuk. Konseling, kesenian, olah raga, dapat menjadi sarana untuk katarsis ini. Satu hal yang perlu diperhatikan dalam pengadaan media katarsis. Jika relawan menyediakan diri untuk mendengarkan, maka idealnya dia ada dalam kondisi yang stabil karena ja akan mendengarkan cerita yang mungkin tidak pernah dibayangkannya. Kemampuan untuk fokus pada orang yang curhat menjadi sangat penting. Meski demikian, penulis tidak mengingkari adanya kemungkinan relawanpun mengalami kejenuhan atau stres tersendiri karena banyaknya informasi emosional yang diterima dan belum mampu mensistematisasi dan mengabstraksinya. Disinilah mengingatkan perlunya relawan "lingkar ke dua" sebagai pendukung relawan "lingkar pertama" yang langsung terjun ke lapangan. Relawan "lingkar ke dua" atau supporting team ini akan menjadi sarana katarsis bagi relawan "lingkar pertama" tersebut.

Memberikan dukungan atau bantuan tidak terlepas dari cara yang tepat. Penulis menyarankan suatu rangkaian keterampilan yang diperlukan para relawan dalam memberikan dukungan sosial. SMEPPPA adalah akronim dari Senyum, Mendengarkan, Empati, Peka, Peduli, Pandai memilih kata bijak, dan Aksi.

Penerimaan adalah suatu bentuk dukungan sosial, dan senyum adalah ekspresi wajah yang mudah untuk itu. Namun demikian, tidak semua orang dapaf dengan mudah tersenyum. Senyum yang tulus darj hati sering kali sulit dilakukan terutama jika antara pikiran dan hati sedang tidak sejalan. Tidak jarang, wajah yang tidak terbiasa tersenyum tidak dapat menunjukkan penerimaan yang sebenarnya ada pada seseorang.

Mendengarkan adalah satu tindakan yang membutuhkan keterampilan pula. Mendengarkan musik adalah hal mudah karena tidak perlu terjadi interaksi. Mendengar orang lain bercerita, sebaliknya, merupakan hal yang tidak mudah karena dalam interaksi ini seseorang perlu menempatkan fokus perhatiannya pada orang yang didengar dan terutama ceritanya. Orang dapat saja dalam posisi mendengarkan tetapi pikirannya sedang tertuju pada hal yang lain, dan akibatnya apa yang didengarnya tidak dipahami secara tuntas. Hal semacam ini dapat mengecewakan orang yang bercerita karena ia merasa tidak diperhatikan dan dinomor-duakan.

Empati adalah kemampuan untuk merasakan atau berpikir dengan cara atau sudut pandang orang lain. Memberikan dukungan sosial tanpa kemampuan empati merupakan suatu hal yang sulit. Seorang relawan perlu memastikan bahwa apa yang 
dia lakukan atau katakan terjadi pada saat yang tepat, sehingga apa yang dilakukan atau dikatakannya mempunyai efek yang positif.

Peka adalah kemampuan untuk mengenali tanda-tanda dan perubahan yang terjadi pada orang lain. Peka dan peduli akan menjadi satu paket karena ketika orang peka namun tidak peduli terhadap orang lain, dukungan sosial tidak akan terwujud. Orang yang peduli akan selalu menanyakan apa yang dapat dilakukannya untuk menolong orang lain.

Berbicara mungkin adalah hal yang mudah. Berbicara dengan kata bijak tidak semua orang mampu melakukannya. Pilihan kata, selain mencakup penghargaan, juga perlu kata-kata yang memotivasi, dan memberi kekuatan pada orang yang diajak bicara. Satu prinsip dari teori belajar dengan kondisioning instrumental adalah bahwa perilaku yang mendapat umpan balik positif akan cenderung diulangi sedang yang mendapat umpan balik negatif akan cenderung dihentikan (Huffman, et al., 1991). Penghargaan biasanya mempunyai efek positif sehingga orang akan termotivasi melakukan sesuatu yang dihargai. Katakata bijak adalah kata-kata yang menenangkan dan bukan menimbulkan rasa terluka dan direndahkan, dan akan mendorong korban untuk memperkuat usahanya mengatasi masalah kehidupan.

Thomas Alva Edison menekankan bahwa perilaku positif seharusnya menjadi kebiasaan dalam hidup. Dengan demikian, keterampilan dan pemahaman akan SMEPPPA hanya akan menjadi pengetahuan jika tidak dilakukan aksi, atau tindakan.

Dengan uraian di atas penulis menekankan pentingnya konsep-konsep psiklogi dalam hubungan antar manusia, terutama dalam peran memberikan bantuan psikologis pada korban bencana. Berikut ini adalah gambar dasar pikiran penulis tentang peristiwa bencana dan peran psikologi dalam proses recovery korban bencana.

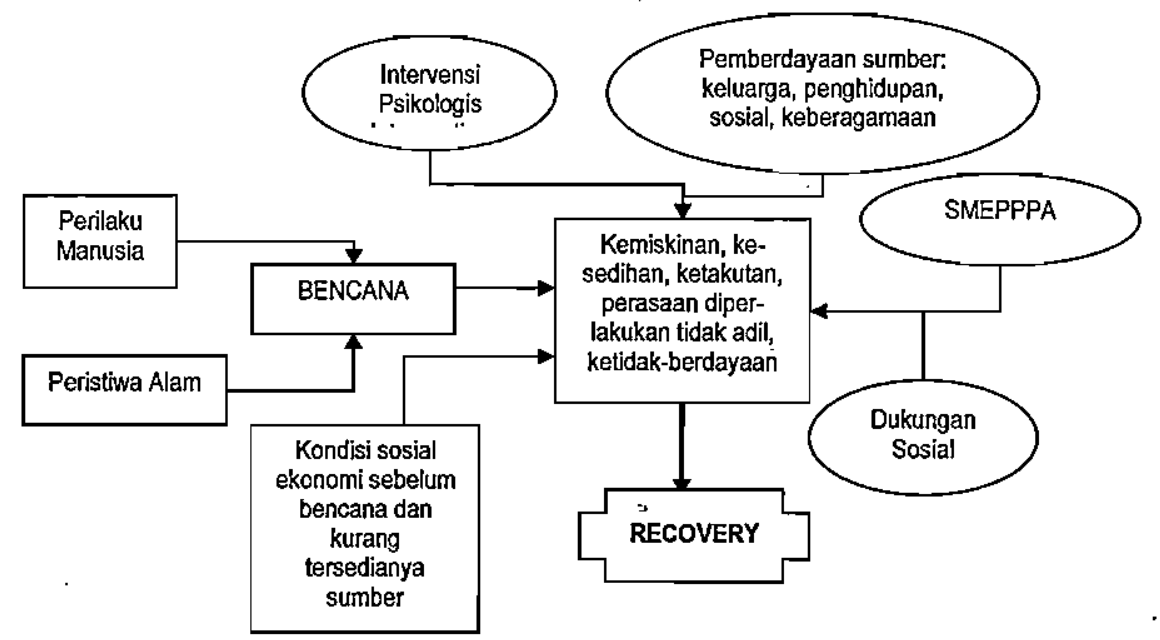

Gambar 2.Bencana dan Peran Psikologi Menuju Recovery Korban Bencana 


\section{Mengolah Rohani dengan Pendekatan Psikologi}

Persoalan bencana merupakan persoalan yang tidak pernah dipikirkan atau diduga sebelumnya. Pemahaman tentang bencana, terutama di wilayah negara Indonesia, seharusnya sudah ada karena pelajaran ilmu bumi di Sekolah Menengah sudah menjelaskan bahwa letak indonesia adalah di jalur magma bumi sehingga di sana banyak ditemukan gunung berapi. Penjelasan tentang ini biasanya berhenti sampai di sini, tanpa banyak hal dibicarakan tentang kemungkinan bencana yang akan terjadi.

Sekarang ini, setelah Indonesia dilanda berbagai bencana, seharusnya pemahaman tentang bencana alam makin ditingkatkan. Bencana alam akan menjadi bagian dari kehidupan penduduk Indonesia, dimanapun tempat tinggalnya.

Pemahaman tentang bencana akan menjadi dasar bagaimana pengambilan keputusan dan kebijakan dalam pembangunan. Masalah lahan tempat tinggal, konstruksi bangunan, kesiapan-kesiapan tindakan jika terjadi bencana akan didasari oleh pemahaman tentang bencana ini. Peristiwa bencana secara tidak terduga telah menguak ketidak-jujuran dan korupsi yang banyak terjadi di Indonesia. Korupsi dalam konstruksi bangunan dan jalan, dengan mudah dan cepat terkuak lewat gempa bumi sesaat. Dengan demikian, bencana alam telah mengajarkan pada kita bahwa perencanaan ke depan perlu memperhatikan masalah kondisi lingkungan, dan pelaksanaan pembangunan tidak dapat sembarangan dan korupsi bentuk apa pun akan terkuak, cepat atau lambat.

Meski kesadaran akan bencana dapat mempersiapkan perilaku manusia, tidak dapat dipungkiri bahwa kecemasan dan ketakutan akan tetap menghantui, dan hal ini sebagaimana telah disinggung sebelumnya, dapat menular pada banyak orang. Selalu ada dalam kecemasan dan ketakutan akan merupakan stres tersendiri pada seseorang atau sekelompok orang. Dengan beban psikologis seperti ini orang akan mengalami disfungsi dalam berbagai perannya. Akibatnya, banyak hal di seputar individu akan berjalan tidak dengan semestinya. Keluarga yang seharusnya menjadi tempat berlindung dan memberikan rasa aman justru menjadi tegang; organisasi pemerintahan menjadi kacau; lingkungan hidup menjadi tidak aman dan nyaman lagi. Oleh karena itu, kegiatan psikologi, selain mendukung peningkatan kesejahteraan dan kemandirian korban, perlu pula mengenalkan korban akan suatu cara mengatasi stres, yaitu dengan kemampuan melihat makna dibalik peristiwa gempa.

Sudah banyak terdengar, muslim menyatakan dan meyakini bahwa "Allah tidak akan memberi cobaan kepada umat Nya di luar batas kemampuan manusia untuk mengatasinya." Keyakinan seperti ini perlu dimantapkan pada para korban bencana. Korban perlu meyakini bahwa "segala cobaan Allah tidak lain adalah 'surat cinta' kepada umatNya untuk mampu melihat makna di balik sebuah peristiwa." Dengan keyakinan in pula korban diarahkan untuk tetap termotivasi untuk bangkit dari masalah yang dihadapinya. Pemantapan keyakinan yang mengolah sisi rohani manusia seperti ini dalam bahasa psikologi disebut sebagai memperkuat strategi coping.

Dari banyak strategi coping yang dikenal ada satu strategi yang terfokus pada emosi, dan bukan pada penyelesaian masalah. Strategi coping pasif terdiri dari sekelompok perilaku yang intinya tidak menyelesaikan masalah (Sabourin et al., 1990). Adalah suatu strategi pasif yang 
disebut resignation atau penerimaan. Penerimaan terhadap apa yang terjadi dan dialami akan membantu individu untuk lebih fokus pada hal-hal yang lebih penting dalam hidupnya.

Dengan memantapkan keberagamaan yang dimiliki korban strategi coping menerima dan selanjutnya mampu mengambil hikmah dari cobaan akan membantu korban mengatasi masalah emosional akibat kehilangan. Bersedih karena kehilangan adalah hal yang wajar, namun kesedihan berkepanjangan juga tidak ada gunanya. Energi yang masih dimiliki oleh korban selanjutnya dapat diarahkan untuk membenahi kehidupan yang terus berjalan.

\section{Penutup}

Sudah saatnya setelah Indonesia mengalami berbagai bencana, psikologi meningkatkan perannya dalam penanganan korban bencana. Peningkatan peran ini tidak hanya dari sisi tanggap dan metode pemberian bantuan. Ditinjau dari permasalahan yang dihadapi para korban psikologi perlu memantapkan suatu pola baku tentang apa yang harus dilakukan. Pergerakan psikologi tidak dapat dilakukan secara awam sehingga perlu banyak persiapan. Di samping itu, pergerakan psikologi tidak selalu efektif jika dilakukan dengan basis individual. Pendekatan kelompok masyarakat menjadi sangat penting mengingat dampak bencana tidak hanya dirasakan oleh beberapa orang saja melainkan oleh banyak anggota masyarakat. Psikologi, dengan pendekatan klinis dan sosial, akan lebih efektif menuju recovery korban bencana.

Peran psikologi, yang terfokus pada proses mental dan perilaku, tidak dapat terfokus hanya pada penanganan stres dan meningkatkan perilaku pemecahan masalah. Strategi coping pasif dalam hal ini penerimaan dan pasrah kepada sang Pencipta merupakan hal penting untuk ditingkatkan, selain coping aktif untuk memecahkan masalah. Dengan demikian, psikologi perlu pula menggunakan pendekatan agama agar penanganan korban gempa secara individual dapat dilakukan secara holistik.

\section{Daftar Pustaka}

Afiatin, T., \& Andayani, B. 1998. "Peningkatan Kepercayaan Diri dan Harga Diri Remaja Penganggur Melalui Kelompok Dukungan Sosial," Jurnal Psikologi, 2, Desember, 1998.

Huffman, K., Vernoy, M., Williams, B., \& Vernoy, J. 1991. Psychology in Action, 2nd ed., New York: John Wiley $\&$ Sons.

Ignacio, L.L and Perlas A.P, 1994. From Victims to Survivors: Psychosocial Intervention in Disaster Management. Manila: IPPAO

Koentjoro, 2006. Penanganan Korban Paska Gempa (Perspektif Psikologi). Makalah Seminar Peringatan Satu Bulan Peristiwa Gempa di Yogyakarta, diselenggarakan oleh UGM, 27 Juni 2006, di UGM.

Koentjoro. 2006. Penanganan Psikologis Korban Gempa pada Tahap Rekonstruksi dan Rehabilitasi. Makalah Diskusi Komisi E DPRD Propinsi DIY dengan LSM dan Mitra Kerja, 16 November 2006.

Mallinckrodt, B.. dan Fretz, B.R. 1988. "Social Support and the Impact of Job Loss on Older Professionals." Jour 
nal of Counseling Psychology, Vol. 35, 3, 281-286.

Oford. J. 1992. Community Psychology: Theory and Practice. Chichester: John Wiley and Sons, Ltd.

Raharjo, W dan Hendratno, A. 2006. Seputar Gempabumi dan Tsunami di Jawa 2006.

Power Point. Yogyakarta: Jurusan Teknik Geologi, Fakultas Teknik UGM.

Sabourin, S., Laporte, L., \& Wright, J. 1990. Problem Solving Self-Appraisal and Coping Efforts in Distressed and
Nondistressed Couples. Journal of Marital and Family Therapy, 16, 1, 8997.

Sarafino, E.P. 1990. Health Psychology: Biopsychological interaction. New York: John Wiley and Sons.

Sunarto. 2006. "Problem dan Antisipasi Kegempaan." Makalah Seminar Peringatan Satu

Bulan Peristiwa Gempa di Yogyakarta, 27 Juni 2006, di UGM. 